\title{
The Role of the Adult Basic Education and Training in Adressing Human Rights in Rural Communities in South Africa
}

\author{
Baloyi, GP \\ College of Education, Department of Adult Basic Education and Training, \\ University of South Africa, P.O. Box 392, Unisa 0003 \\ Tel: 012429 2646, Fax: 012429 8812, Email: baloygp@unisa.ac.za
}

\section{Doi:10.5901/mjss.2014.v5n2p613}

\begin{abstract}
Human rights are topical and the importance thereof crucial in developing the rural communities in South Africa. In South Africa, most people's rights are undermined. Examples of human rights being abused or under threat, especially among Africans, are plentiful in the media. The researcher will discuss education as a basic right to adults through the Kha ri gude mass literacy campaign. Most University of South Africa (Unisa) students are from rural communities and they have a role to play in educating the public about human rights, social justice and education. Unisa has been mandated to widen participation in South Africa's higher education. It is in this regard that the researcher is motivated to conduct the study and see the difference that the institution can make in the lives of the people. The researcher will interview Kha ri gude students to understand the role they can play to ensure education and social justice in South African communities. The theoretical framework of ubuntu will be used to understand the study project. The study will propose some ways and means of assisting the communities in dealing with access to basic education.
\end{abstract}

Keywords: human rights, social justice, education, ubuntu, open distance learning, rural

\section{Introduction and Background to the Study}

The ministry of education has introduced the Kha ri gude litereacy campagin to address illiteracy in South Africa. Kha ri gude is a Tshivenda expression which means, "let us all learn". It is a national campaign run under the auspices of the Department of Basic Education. Most teachers who teach in this campaign have enrolled at the Adult Basic Education and Training (ABET) department. The department has a history of addressing the issues of illiteracy in South African communities. The paper argues that education is a right and that adult education is a continuing commitment to a right based social order. It is in this context that the researcher discusses the role of the University of South Africa (Unisa) in contributing to human rights education and social justice.

When the researcher joined the Adult Basic Education and Training (ABET) department almost three years ago, it was a fulfilment of his childhood dream of working in an institution of higher learning and contributing to social justice in adult education. For some sectors of the society, adult education was neglected before the predemocractric era.

The Department of Education released the Adult Basic Education and Training (ABET) Act 52 of 2000 on 15 December 2000. The Act seeks to regulate adult basic education and training; to provide for the establishment, governance and funding of public adult learning centres (PALCs); to provide for the registration of private adult learning centres; to provide for quality assurance and quality promotion in adult basic education and training; to provide for transitional arrangements; and to provide for matters connected therewith (Government Gazette No. 21881, Adult Basic Education and Training Act, 52 of 2000) (Ibid.). The adults in the democratic South Africa have a basic right to education which has been denied to them in the past.

Adult Basic Education and Training is the general conceptual foundation towards lifelong learning and development, comprising knowledge, skills and attitudes required for social, economic and political participation and transformation applicable to a range of contexts. ABET is flexible, developmental and targeted at the specific needs of particular audiences and, ideally provides access to nationally recognized certificates. The policy is itself shaped by broader education policy represented in the White Paper of 1995, the National Education Policy Act of 1996 and the South African Qualifications Act of 1995. The department has through its Adult Education and Training (AET) Directorate engaged in a number of activities to build up an ABET system that enables ABET provision based on principles and practices of equity, redress, development, reconstruction, access, integration, partnerships, sustainable use of resources, 
a flexible curriculum, outcome-based standards of attainment, the recognition of prior learning and cost effectiveness (Ibid.).

ABET involves more than just literacy. It is intended to serve a range of social, economic and developmental roles and it is also viewed as fundamental to bring about the dignity and self-esteem of the learner (Ibid.).

Adult education is crucial for social change globally. According to Belanger (2011:18), accessibility to ABET programmes remains a challenge globally. Adult education addresses socio-economic problems through empowering people with skills. All citizens should have the opportunity to develop themselves throughout their lives at whatever age, acquire the knowledge and know-how to better pilot life transitions, improve their quality of life, develop their potential and experience the joy of learning. Belanger (2011) also identifies financial factors as inhibitors of adult education. This could be attributed to the global economic crisis. Notwithstanding adult education is the best investment governments can make to sustain an efficient and therefore participatory welfare state. This will yield results in all areas of activities, including the economy and the world of work (Belanger 2011:20). The Kha ri gude campaign is provided at no cost to the society. The following discussion provides the context of Unisa and adult education.

\section{Adult Basic Education and Training in the South African context}

The ABET sector in South Africa was ignored before 1994. Unisa established an institute to deal with adult education with the focus of addressing literacy in South Africa. Thereafter adult education became one of the priority areas targeted by the government in the democratic era. In 2000 the ABET Act was passed which enabled the establishment of public and private adult learning centres. The Act seeks to regulate adult basic education and training; to provide for the establishment, governance and funding of public adult learning centres (PALCs); to provide for the registration of private adult learning centres; to provide for quality assurance and quality promotion in adult basic education and training; to provide for transitional arrangements; and to provide for matters connected therewith (Adult Basic Education and Training Act, 2000).

As in most developing countries, South Africa has low levels of literacy which could be attributed to the apartheid era during which many people received very little or no formal education at all.

According to the Department of Education (2004:5) more than a third of South Africans sixteen years old and older are illiterate. It also suggests that literacy should be alleviated through the provision of Adult Basic Education and Training (ABET) to redress discrimination and past inequalities. The government came out with literacy campaigns such as Kha ri gude and other extended community projects.

The government also came to realize that the people who were suffering were those who grew up during the apartheid era and who received very little or no education at all. During the democratic era ABET was identified by the government to address the problem of illiteracy in South Africa.

The ABET institute at Unisa and other ABET centres in universities such as the University of KwaZulu-Natal, the Witwatersrand and Western Cape, played an important role in training ABET practitioners in South Africa during the democratic era.

Mckay (1995) indicates that those who have never been to school or have had very little education have not only missed learning to read and write, but they have also been deprived of essential skills and the other benefits that people acquire from attending school. The Constitution of the Republic of South Africa identified education as a moral concept. According to Baatjies (2004) ABET has been constitutionally enshrined as a basic right of all citizens and a legal entitlement to which every person has a claim. ABET can be described as the foundation for justice and equality and thus contributes to the core values adopted for South Africa. Section 29(1) of the Constitution of the Republic of South Africa states "everyone has the right to basic education including adult basic education and to further education, which the state, through reasonable measures must make progressively available and accessible" (Rule 2006:114).

According to MacGregor (2008), ABET is booming in South Africa. However, other literacy campaigns such as Project Literacy indicated that South Africa has 4, 7 million illiterate people who have had no schooling. Another 4, 9 million adults are functionally illiterate to varying degrees. Some dropped out of school before grade 7 . The greatest problem lies with adults who grew up before 1994 and received very little formal education. Low levels of literacy and numeracy persist among these people. The Kha ri gude literacy campaign came to address some of the issues that the literacy project failed to address in the past.

McKay, Kotze, Vacarrino and De Necker 1998 in Quan-Baffour and Vambe (2006:300) remind us that the rural areas of South Africa suffer from poor infrastructure. In these areas more than any others, adult education driven by a multimedia-enhanced delivery approach can have a fundamental impact. Furthermore, $48 \%$ of South Africans live in rural 
areas. However, this situation is not peculiar to South Africa. Rural people who live and work in scattered areas need to be empowered through education.

According to Unisa policies, a significant example of how adult educators for ABET can be trained using distance education was the former ABET Institute at Unisa, which has now been reconstituted as a full academic department. ABET students are diverse, often located in rural areas where there are no facilities. The students enrolled in the ABET department are taught generic ABET skills that enable them to teach and work in a range of areas including the Kha ri gude literacy campaign.

The Unisa ABET Institute was established in 1995. It has trained adult educators both in and outside South Africa. Most of the students of the institute are community builders, non-governmental organization (NGO) staff and adult educators. According to 2003 figures, the Institute boasted a 187 dedicated part time tutors and 33 coordinators on the ground (scattered all over the country), all of whom offer academic and other support that ABET distance learning students need so urgently if they are to cope with their studies. These tutors consist of 102 females and 85 males, supported by the 33 coordinators.

In 2005 over 12000 students enrolled for the various courses in ABET. The success of the institute in its teaching programme stems from good management and effective student support (Quan-Baffour \& Vambe 2005:39).

According to MacGregor (2008), Unisa has trained 80000 ABET practitioners since mid-1990. The aim is for these graduates to participate in a huge literacy campaign in South Africa. The former institute had 17 staff members; 17000 students were registered in 2008. The students were provided with course packs including audio and visual material; 300 tutors throughout the country supported these students. The ABET Institute identified, selected and appointed tutors who were committed and qualified ABET practitioners living or working in rural areas. These part-time tutors were former senior students or individuals identified by the Institute for their good work in the communities as adult educators including the Kha ri gude literacy campaign. The tutors concerned contacted their students through SMS, word of mouth, announcements at churches and schools, advertisements posted at post offices, shops, education offices, and where possible, local radio and newspaper announcements. Through these various communication media, Unisa ABET students were informed of venues of tutorials and meetings. These are some of the innovative ways in which Unisa contribute to the socio-economic development of communities.

The Unisa ABET Institute's student support system is unique because it caters specifically for students in the rural areas where there is high illiteracy rate. Unlike the learning centres based only in towns and cities, in the rural areas as few as 15 ABET students can be assigned to a tutor who usually lives in the same area and thus within the vicinity of his or her tutorial group. The small groups offer these students effective interaction between them and their tutors. The ABET Institute's management believe that as distance education providers, it is their moral responsibility to support students, particularly those who live under difficult conditions in the rural areas. Once or twice a month the Unisa ABET students in a particular rural geographical region meet at a convenient venue in their district for two to four hours to share their experiences of the study material. During 2010 the Institute became the Department of ABET at Unisa and started to offer formal programmes.

\section{Context of the Participants}

The data was collected in the Greater Tzaneen municipality in Limpopo Province. The two areas, Khujwana and Shiluvana villages were visited. The participants in the discussion sessions were Pedi and Xitsonga speaking. The researcher met with eighteen Kha ri gude students and two supervisors. The students consisted of Fourteen females and Four males (One disabled) and One male representing the Council of the area and two Kha ri gude supervisors. There were more females than males in both sessions. The focus group sessions were held where students were asked questions in the interview guide for group discussion. The researcher asked them the questions and they were afforded an opportunity to add or modify the interpretation of the responses. They were also given an opportunity to comment on the researcher's interpretation of the gist of the discussion.

\section{Limitation of the Study}

Although the Kha ri gude is a national literacy campaign, the research project was restricted to the Greater Tzaneen municipality in Limpopo Province. The views presented in this study are only of the students within the municipality and cannot be generalised to all South Africans. 


\section{Methodology, Discussion and Data Analysis}

The researcher met with supervisors and students involved in the Kha ri gude programme during focus groups. The group was given ground rules to follow during the proceedings. For example, only one person must talk at a time, participants must respect each other's views, agree or disagree politely.

The purpose of this group session was to determine whether and how the Kha ri gude programme helped in the development of the community, for instance, whether the programme offered income-generating skills, opportunities to gain employment and whether the programme meets the needs of the community.

The type of group that was in the sessions was participating fully. This was so because the researchers could reach out to them when questioning them. The researcher also precisely built the rapport and the atmosphere of trust to participants. They were attracted with the researcher's facilitation skills during the focus group and won their trust. The participants were trained to be active citizen in the society. During the focus group the researcher told them that it was a day where we are celebrating the Kha ri gudeKha ri gude. During the sessions the participants indicated that they can read and write, and can no longer send their children to bank, they go on their own. Previously, when they send their children to bank they would withdraw the entire money in their cards. Tomorrow when they send somebody to withdraw there is no money. The researcher had a listening skill for the participants. What also contributed a lot to their participation was the way the researcher established a rapport. These have greatly determined their participation.

There are more female than men in Kha ri gude classes. In the Kha ri gude programme there are more women than men. This is precisely so because women were discriminated by the culture to go to school in the past. The participants were interviewed to find out whether the Kha ri gudeKha ri gude has empowered them to gain skills to empower themselves and the society. Most of them are elderly and they do not have the opportunities to go and look for the jobs. They are comfortable where they are because the majority of them are adults. The questions were not rigid, students were also given an opportunity to add information, so they added as many information as they wanted. Sometimes they always talked about issues that were not related to the question.

In this area the most important community project involves farming. The participants had farming projects such as rearing chicken, goats and other animals. The Kha ri gude campaign is also linked to other community projects that empower the people in the society. Most participants are sent to Kha ri gude in order to learn to read and write enabling them to manage their community projects. When reading and writing have been matered they can proceed to other programmes, such as learning how to care for the sick in the communityies. They plant herbs to cure the sick who cannot afford to go to health facilities, and they work with the HIV and Aids care givers in some of their projects. They supervise school children in their homes and children in child-headed families.

They are also involved in chicken farming, goat farming and water projects. Their ability to read and write enables them to apply for water to the schools throughout the Greater Tzaneen Municipality. They take care of orphans and vulnerable children. Through their engagement in the campaign, they can fully participate in socio-political order in the communities. They assist the schools in cooking food for the children and distributing food parcels to the children. They care for all children in the community without discriminating. They assist with Sunday schools, feed and clothe the needy children who are at schools. They patrol the community and take the children who are roaming the street back to the schools. These are not street children like in the urban areas, but children who skip school. They are also involved in scholar patrols that manage the traffic to ensure the children's safety. The spirit of ubuntu is evident in the way they care about each other in the community. They work with various stakeholders in the community to develop the community as a whole.

Although they sometimes sell tomatoes to earn some money, their service to the community is not about monatory reward, but to serve community members who are in need. They go door to door to identify sick people in the community and refer them to where they will be helped. They are involved in building projects to help community members who do not have shelters. They advise the community to spend their grants and pensions wisely. The Kha ri gude campaign made the people to be critical thinkers. The participants have counselling skills and offer services in the community to children who abuse drugs. Because of their involvement in Kha ri gude, they help each other to deal with difficulties, for example health issues. Now that they are able to read and write they can assist their children with homework. They are able to check their children's books to check-their progress.

\section{Recommendations}

The illiteracy rates are higher in rural areas than in urban areas. A large number of people in rural areas have not 
attended schools. Women were identified by the ABET programme as the group who need special attention because previously they were denied schooling. In their recommendations, the participants needed the following: Most participants has graduated with level one qualifications and they needed to proceed to the next level, they would like to proceed further because education involves lifelong learning, they needed more land for farming, introduction of sporting activities for the aged and to open centres for orphans and vulnerable members.

The discussion session was concluded with the observation that Kha ri gude has motivated them to learn, but unfortunately the ABET centres are very far from their areas and they would like the programme to be brought closer to them. The campaign has taught them to be critical thinkers in the society. They are able to take care and improve their health and the health of others in the community much better. Now that they can read and write, they are able to check their children's homework and also assist where they find it possible. They are involved in the community projects without remunerations.

\section{References}

Belanger, P. 2011. Onto new horizons. Adult Education and Development, 77: 17-20.

Department of Education. 1997. Policy Document an Adult Basic Education and Training. Pretoria: Government Printing

Department of Education. 2001. Building and ABET system: The First Five Years. 1995-2000.

MacGregor, K. 2008. South Africa: Boom in adult basic education. University World News. Available at: http://www.universityworldnews.com /article.php?story=20080314090614219.

Quan-Baffour, K.P. \& Vambe, M.T. 2006. Multiculturalism and learning technologies in Adult Basic Education and Training programs at the University of South Africa. Research and Practice in Technology Enhanced Learning, 1(3): 297-308.

Rule, J. 2006. The time is burning: The right of adults to basic education in South Africa. Journal of Education, 39: 114-135. 
